\title{
Zinc Finger C2HC Domain-Containing Protein 1B
}

National Cancer Institute

\section{Source}

National Cancer Institute. Zinc Finger C2HC Domain-Containing Protein 1B. NCI

Thesaurus. Code 190033.

Zinc finger $\mathrm{C} 2 \mathrm{HC}$ domain-containing protein 1B (222 aa, $25 \mathrm{kDa}$ ) is encoded by the human ZC2HC1B gene. This protein may be involved in basal-like breast cancer. 